\title{
STRATEGI PENINGKATAN MUTU PERPUSTAKAAN PERGURUAN TINGGI MELALUI KETERSEDIAAN BAHAN PUSTAKA
}

\author{
Murnia Arief \\ Pustakawan Universitas Trunojoyo Madura \\ murnia.arief@trunojoyo.ac.id
}

\begin{abstract}
ABSTRAK
Menciptakan kualitas perpustakaan diperlukan beberapa komponen utama serta tidak untuk diabaikan sebagai upaya meningkatkan kualitas maupun mutu akademik dalam rangka menuju perguruan tinggi berkelas dunia (World Class University). Kaitan meningkatkan mutu perpustakaan perguruan tinggi bukan sekedar tugas secara teknis semata, namun ada hal yang perlu serta dipersiapkan, diantara hal tersebut diperlukan strategi dan kajian yang mendalam tentang visi, misi dan tujuan perpustakaan perguruan tinggi secara obyektif. Artikel ini mengkaji masalah yang terkait dengan ketersediaan bahan pustaka di perpustakaan perguruan tinggi sehingga berdampak dan berimplikasi untuk memenuhi kebutuhan pemustaka untuk mewujudkan perpustakaan berkualitas. Metode yang digunakan dalam penelitian ini melalui kajian literatur, dari hasil penelitian didapatkan bahwa ketersedian dan kelengkapan bahan pustaka merupakan salah satu strategi yang dapat meningkatkan mutu perpustakaan perguruan tinggi.
\end{abstract}

Kata Kunci : perpustakaan perguruan tinggi, kebutuhan informasi, kualitas layanan, ketersediaan bahan pustaka.

\section{PENDAHULUAN}

Sebagai organisasi mendokumentasikan dan menyebarluaskan sumber informasi, tentunya perpustakaan memiliki peranan penting terkait dengan kebutuhan informasi penggunanya, hal tersebut merupakan prinsip dasar tugas serta misi perpustakaan sebagai wahana edukatif. Sebagai institusi atau organisasi di perguruan tinggi, perpustakaan bisa dikatakan sebagai barometer jika dapat mewujudkan iklim pendidikan dan meningkatkan prestasi mahasiswa. Adanya peran perpustakaan maka proses belajar mengajar menjadi lebih lancar dan efektif. Ketersediaan bahan pustaka di perpustakaan merupakan faktor utama yang harus disediakan oleh pustakawan dengan memperhatikan kepentingan stakeholder.

Ketersediaan bahan pustaka merupakan salah satu strategi untuk menarik peminat pemustaka memanfaatkan perpustakaan. Sumber informasi di perpustakaan merupakan penghubung antara informasi dan pemustaka. Menurut Sarwono (2010), perpustakaan sebagai organisasi sumber informasi sebuah nadi untuk menggerakkan lembaga pendidikan sehingga dapat beradaptasi terhadap ledakan informasi. Perpustakaan bisa dikatakan memiliki mutu maupun kualitas jika ketersediaan bahan pustaka tersebut sesuai fungsi ataupun tujuan 
daripada perpustakaan masing-masing. Dari penjelasan dapat ditarik kesimpulan, bahwasanya mutu maupun kualitas dari sebuah layanan di perpustakaan tidak lepas melalui ketersediaan bahan pustakanya, dimana bahan pustaka tersebut fokus pada pemustaka. Setiap perpustakaan memiliki perbedaan karakteristik dalam konteks bahan pustaka, hal tersebut menyesuaikan fungsi maupun tujuan daripada lembaga induk, tetapi visi semua perpustakaan memiliki kesamaan yaitu ketersediaan bahan pustaka secara lengkap. Batasan kelengkapan bahan meliputi tingkat kesesuaian jumlah program studi serta kurikulum yang ada, jadi dalam pengembangan perpustakaan isu ketersediaan bahan pustaka selalu menjadi fokus utama.

Dalam hal ini penulis menitik beratkan bidang perpustakaan, dengan mengkaji ketersediaan bahan pustaka sebagai indikator strategi peningkatan mutu perpustakaan perguruan tinggi. Penulis tertarik dengan fokus ketersediaan bahan pustaka, hal tersebut bisa dilihat dari pemustaka yang merasa kesulitan untuk mendapatkan sumber informasi/literature sebagai salah satu sumber bahan pustaka untuk mengembangkan bidang kompetensi. Kebutuhan sumber informasi, terkait dengan bahan pustaka salah satu tugas perpustakaan untuk menyediakan bagi kepentingan pemustaka, adanya ketersediaan tersebut menghasilkan pemanfaatan perpustakaan oleh pemustaka sehingga tercipta proses pendidikan. Untuk memenuhi kebutuhan pemustaka setiap perpustakaan perguruan tinggi, khususnya perguruan tinggi negeri memerlukan sebuah media yang berfungsi sebagai pemenuhan sumber informasi pemustaka berupa, penghimpunan serta pelayanan untuk pemustaka.

Pemenuhan sumber informasi dan ketersediaan bahan pustaka bermakna berbanding lurus. Apabila kebutuhan sebuah informasi tinggi maka ketersediaan bahan pustaka pun harus selaras terhadap kebutuhan tersebut. Ketersediaan bahan pustaka di perpustakaan perguruan tinggi, wajib memiliki kelengkapan dan mutu baik dari komposisi jumlah, maupun variasi judul sehingga bernilai guna untuk memenuhi kebutuhan pemustaka di lingkungan pendidikan tinggi. Cerminan perpustakaan sebagai pusat sumber informasi civitas akademik, ketersediaan bahan pustaka perpustakaan perguruan tinggi negeri sebagai fungsi layanan dan pemenuhan kebutuhan sumber informasi.

Dari kesimpulan diatas terdapat pengaruh signifikan antara kebutuhan sumber informasi dan ketersediaan bahan pustaka di perpustakaan, khususnya perpustakaan perguruan tinggi negeri. Keduanya memiliki hubungan fungsional tidak dari sebelah sisi saja, namun kebutuhan sumber informasi merupakan kebutuhan dasar untuk menciptakan ketersediaan bahan pustaka untuk diberikan oleh pemustaka.

\section{TINJAUAN PUSTAKA}

\section{Perpustakaan Perguruan Tinggi Negeri}

Sebagai organisasi yang dikelola pemerintah bertugas menyebarluaskan serta mendokumentasikan sumber informasi, perpustakaan perguruan tinggi negeri memiliki kepentingan melaksanakan tri dharma perguruan tinggi. Untuk melaksanakan hal tersebut perpustakaan tidak melaksanakan secara mandiri, namun dengan kerjasama antara fakultas untuk menghimpun maupun melayankan sumber informasi kepada pemustaka, khususnya civitas akademika.

Pengembangan perpustakaan perguruan tinggi bertujuan guna mendukung visi dan misi perguruan tinggi tersebut. Dalam kaitannya dengan visi dan misi, perpustakaan juga 
berfungsi sebagai pusat informasi yang berhubungan dengan penelitian dan pengabdian masyarakat. Dengan melihat karakteristik serta fungsi maupun masyarakat yang dilayani serta kedudukannya. Agar perpustakaan perguruan tinggi negeri bisa terus berkembang, maka diperlukan untuk melakukan kerjasama dengan seluruh civtas akademika. Untuk melakukan kerjasama perpustakaan dengan civitas akademika diperlukan SDM yang memiliki mutu, karena SDM merupakan salah satu faktor penting dalam perpustakaan, khususnya pustakawan. Menurut Maswardi (2016), dalam rangka menghasilkan SDM yang bermutu, sebuah institusi memerlukan perumusan dan kebijakan untuk merujuk pada peningkatan mutu sebagai strategi.

\section{Fungsi Perpustakaan Perguruan Tinggi}

Dalam rangka menjalankan fungsi sebagai unit pelaksana teknis, perpustakaan perguruan tinggi merupakan salah satu penunjang tri dharma perguruan tinggi untuk menjalankan fungsi pendidikan, penelitian dan pengabdian masyarakat, untuk itu perpustakaan berkewajiban memenuhi kebutuhan pemustakanya. Menurut Yuven (2010), fungsi perpustakaan perguruan tinggi memiliki beberapa hal, yaitu:

1. Pusat belajar (study center), artinya perpustakaan sebagai pusat pembelajaran yang berfungsi sebagai penunjang tri dharma perguruan tinggi menyediakan sumber informasi bagi pemustakanya.

2. Pusat pembelajaran (learning center), artinya perpustakaan dan sumber informasi yang terkandung di dalamnya harus tersedia di civitas akademika yang bertujuan mendukung proses belajar mengajar sesuai dengan UU No 2 Tahun 1989 pasal 35.

3. Pusat penelitian (research center), bahwasanya perpustakaan berkewajiban untuk menyediakan sumber referensi bagi civitas akademika yang bertujuan sebagai data ataupun sumber informasi penelitian.

4. Pusat sumber informasi (information resources center), segala sesuatu yang berkaitan dengan sumber informasi, maka perpustakaan merupakan organisasi penyedia sumber informasi.

5. Pusat pelestarian ilmu pengetahuan (preservation of knowledge center), disamping sebagai penyedia sumber informasi tentu perpustakaan salah satu pusat dokumentasi ilmiah ataupun sebagai organisasi memiliki fungsi sebagai grey literature

6. Pusat penyebaran informasi (dissemination of information), perpustakaan tidak sekedar berfungsi mengumpulkan sumber informasi, tetapi memiliki fungsi sebagai pusat promosi informasi

\section{Kebutuhan Informasi Bagi Civitas Akademika}

Era informasi merupakan salah satu dimana masyarakat membutuhkan sumber informasi sebagai sebuah kebutuhan. Kebutuhan aktualisasi diri merupakan sebuah makna informasi sebagai jawaban untuk menghadapi aktifitas kehidupan. Adanya kesenjangan ilmu pengetahuan terjadi berakibat pada kebutuhan informasi, terdapat perbedaan individu yang dilatarbelakangi oleh kemampuan intelektualitas di masyarakat. Menurut Soetminah (1992) keperluan informasi dibedakan berdasarkan strata sosial seseorang. Sumber informasi tersebut tidak terbatas pada bidang ataupun salah satu aspek. Seeking, needs and behavior merupakan salah satu buku karangan Donald O Case menjelaskan kebutuhan informasi 
(needs information) memiliki 2 sudut pandang berupa objektif dan subjektif. Pemanfaatan sumber informasi oleh pemustaka berfungsi sebagai aktualisasi untuk menciptakan karya ataupun prestasi. Sumber informasi yang disediakan oleh perpustakaan bertujuan untuk memenuhi kebutuhan informasi masyarakat pengguna mereka perlu menggunakan bahan pustaka yang tersedia. Fatmawati (2010), menyatakan promosi sumber informasi di perpustakaan perguruan tinggi bisa menjadi salah satu pemanjaan terhadap pemustaka. Kegiatan promosi dilakukan secara berkesinambungan mengingat ilmu pengetahuan terus berkembang dan berubah seiring dengan teknologi.

\section{Kualitas Layanan}

Moenir (1995), sebagai hakikat kegiatan layanan, merupakan salah satu pemenuhan kebutuhan dari serangkaian proses layanan. Hal senada juga diungkap Kotler (2009), pelayanan merupakan kegiatan melalui proses penawaran dari berbagai pihak dengan prinsip tidak berwujud (intangible). Berdasarkan paparan ahli diatas yang menjadi salah satu fokus layanan adalah upaya untuk mendapatkan kualitas layanan yang diberikan oleh masyarakat. Konteks layanan dalam ilmu perpustakaan cara bagaimana pustakawan memberikan layanan terhadap pemustakanya.

\section{METODE PENELITIAN}

Melalui kajian literatur atau literature review dengan menggunakan beberapa jurnal online ataupun penelitian terkait dengan ketersediaan bahan pustaka. Dalam artikel ini penulis berusaha untuk mengidentifikasi tentang ketersediaan bahan pustaka yang menjadi salah satu indikator untuk meningkatkan mutu perpustakaan perguruan tinggi negeri. Dalam kamus bahasa inggris, bahwasanya kajian literatur salah satu metode awal dalam perencanaan penelitian. Kajian literatur merupakan pendekatan melalui penelusuran ataupun penelitian kepustakaan melalui strategi membaca buku, jurnal dan terbitan yang relevan.

\section{HASIL DAN PEMBAHASAN}

\section{Relevansi Ketersediaan Bahan Pustaka Bagi Kebutuhan Civitas Akademika}

Artikel ini membahas tentang ketersediaan bahan pustaka di perpustakaan perguruan tinggi negeri, dimana ketersediaan tersebut merupakan upaya sekaligus strategi perpustakaan untuk memenuhi kebutuhan pemustakanya. Kita tahu bahwasanya ketersediaan bahan pustaka merupakan komponen penting dalam aspek strategi peningkatan mutu layanan. Dalam E. Martono (1987), secara garis besar perpustakaan memiliki, pertama sebagai pelestarian budaya, artinya adanya ketersediaan bahan pustaka di perpustakaan maka partisipasi masyarakat dapat maksimal, khususnya kegiatan penelitian dan pengabdian pada masyarakat di lingkungan civitas akademika. Kedua, meningkatkan prestasi dan kecerdasan masyarakat, artinya bahwa ketertarikan masyarakat pengguna di lingkungan perguruan tinggi dapat dilihat dengan ketersediaan bahan pustaka dalam berbagai sumber. Ketersediaan bahan pustaka dalam berbagai sumber disini meliputi bentuk cetak ataupun non cetak (online), yang tentunya ketersediaan tersebut dapat memenuhi kebutuhan pemustakannya. Ketiga, 
pengembangan perpustakaan dari aspek ketersediaan bahan pustaka sehingga kebutuhan informasi pemustaka dapat dipenuhi Herlina (2013). Tugas perpustakaan untuk mengembangkan ketersediaan bahan pustaka yang memiliki kekuatan demi kepentingan pemustakanya. Untuk memenuhi kebutuhan informasi pemustaka, peran pustakawan sangat dibutuhkan untuk mengamati serta mengembangkan sehingga misi perpustakaan dapat sesuai kebutuhan masyarakat pengguna. Kebutuhan informasi masyarakat civitas akademika bisa dipenuhi apabila pustakawan mampu membuat rencana pengembangan bahan pustaka secara sistematis, dengan tersedianya bahan pustaka yang lengkap maka semua pengguna perpustakaan baik dari kalangan civitas akademika maupun pengguna dari masyarakat luar, akan merasa puas, jadi erat kaitannya antara ketersediaan koleksi dan kepuasan pengguna, seperti hasil kajian yang telah dilakukan oleh Lailatus Sa'diyah ( 2016). Terwujudnya suatu perpustakaan perguruan tinggi yang berkualitas sangat dipengaruhi oleh optimalisasi dari beberapa unsur penting salah satunya yaitu bahan pustaka, hal ini senada dengan hasil penelitian Budi Handari (2016), maka jika suatu perpustakaan perguruan tinggi ketersediaan bahan pustaka lengkap dan memadai, maka dapat dikatakan perpustakaan tersebut berkualitas karena mempu nyediakan secara optimal sumber informasi yang dibutuhkan oleh pemustaka.

\section{Pemahaman Pustakawan Tentang Pengembangan Bahan Pustaka}

Ketika kita berbicara mengenai sebuah layanan, maka pikiran tidak lepas dari perpustakaan. Sebuah organisasi yang bergerak dalam bidang layanan jasa informasi. Ketersediaan bahan pustaka dari berbagai format dan jenis, tentunya bukan sekedar menjadi sebuah pajangan belaka. Namun ketersediaan tersebut memiliki tujuan untuk memenuhi kebutuhan informasi pemustakanya. Tentunya bahan pustaka tersebut memiliki nilai yang sesuai dengan perkembangan ilmu pengetahuan. Tugas bagi setiap perpustakaan untuk membangun ketersediaan bahan pustaka yang kuat demi kepentingan pemustaka. Untuk memenuhi kebutuhan informasi pemustaka, peran pustakawan sangat dibutuhkan untuk mengamati serta mengembangkan sehingga misi perpustakaan dapat sesuai kebutuhan masyarakat pengguna. Kebutuhan informasi masyarakat civitas akademika bisa dipenuhi apabila pustakawan mampu membuat rencana pengembangan bahan pustaka secara sistematis. Menurut Evans (2006), mendefinisikan bahwa pengembangan bahan pustaka merupakan aturan tertulis dari manajemen perencanaan suatu kegiatan dan sumber informasi agar digunakan sebagai pedoman pustakawan dalam kerangka berfikir untuk pengambilan keputusan terkait dengan bahan pustaka ataupun jumlah dari setiap subjek. Pada penelitian terdahulu Futas (1995), melakukan beberapa survey terkait dengan pengembangan bahan pustaka sebanyak 357 perpustakaan perguruan tinggi negeri maupun swasta di wilayah Amerika Serikat, dengan memberikan pertanyaan

"What you have a many collections policy development in the force? So what was first written? was last reviewed?"

Dari hasil beberapa survey yang telah dilakukan sebanyak 3 perpustakaan menjawab "tidak" pada pertanyaan tersebut, sedangkan $72 \%$ menjawab dengan ya pada pertanyaan diatas, dan untuk 28\% perpustakaan di Amerika Serikat tidak memiliki kebijakan pengembangan bahan pustaka hingga akhir tahun 1994. Dari hasil 28\% bahwasanya 
perpustakaan perguruan tinggi swasta yaitu $79 \%$ dan $21 \%$ berasal dari perpustakaan perguruan tinggi negeri. Dari pertanyaan tersebut beberapa pustakawan yang terlibat mengatakan tidak pernah memiliki kebijakan pengembangan bahan pustaka, namun mereka pernah menggunakan kebijakan pengembangan bahan pustaka untuk meningkatkan ketersediaan informasi. Hal senada juga diungkapkan Brophy (2005) bahwa pengembangan bahan pustaka merupakan salah satu manajemen koleksi yang bertujuan untuk meningkatkan ketersediaan bahan pustaka. Selanjutnya Evans (2005) mendefiniskan proses pengembangan bahan pustaka menjadi beberapa hal: 1) Analisis kebutuhan pemustaka, merupakan langkah awal yang bertujuan untuk menentukan maupun menilai serta menganalisa kebutuhan pengguna. 2) Kebijakan seleksi bahan pustaka, langkah kedua membuat pedoman untuk menyeleksi bahan pustaka, tentunya langkah ini diawali dengan analisa kebutuhan. 3) Proses seleksi bahan pustaka, langkah ini digunakan untuk melaksanakan kegiatan seleksi bahan pustaka. 4) Proses pengadaan, kegiatan ini bertujuan melaksanakan kegiatan dari hasil seleksi bahan pustaka berupa data ataupun daftar bahan pustaka, yang selanjutnya digunakan untuk pembelian. 5) Penyiangan bahan pustaka, kegiatan yang dilaksanakan untuk tujuan memilih beberapa bahan pustaka dari komposisi informasi sudah tidak relevan bagi pemustaka. 6) Evaluasi, kegiatan ini digunakan sebagai evaluasi yang berkaitan dengan pemanfaatan. Berdasarkan beberapa pendapat diatas, dapat disimpulkan bahwa untuk mendapatkan ketersediaan bahan pustaka perpustakaan harus memiliki pedoman ataupun panduan tentang kebijakan pengembangan bahan pustaka. Hal tersebut dipandang penting sebab dengan panduan kebijakan pengembangan bahan pustaka perpustakaan akan memperoleh sumber daya informasi yang tepat sasaran, artinya bahan pustaka itu sesuai dengan kebutuhan civitas akademika.

\section{Kebutuhan Pemustaka Terhadap Bahan Pustaka Elektronik}

Era teknologi informasi kebutuhan akan sumber informasi sangat cepat, untuk mengantisipasi hal tersebut berbagai jenis penyimpanan data elektronis telah disediakan oleh perpustakaan. Dalam kaitannya perihal ketersediaan bahan pustaka perpustakaan tidak hanya dituntut untuk menyediakan bahan pustaka cetak (printed), namun hal yang urgensi adalah penyediaan bahan pustaka non cetak (elektronis) untuk memenuhi kebutuhan pemustaka.

Strategi saat ini yang bisa dijalankan oleh pihak perpustakaan dalam rangka mewujudkan perpustakaan di era global antara lain:

1. Mengembangkan bahan baik cetak ataupun non cetak yang memiliki nilai jual.

2. Penggunaan sistem yang dapat dipahami oleh setiap pemustaka

3. Meningkatkan kegiatan layanan sumber informasi

4. Membangun kerjasama antar perpustakaan guna pemanfaatan dan penyebaran sumber informasi

5. Memiliki kepala perpustakaan dan pustakawan yang visioner.

Berkembangnya teknologi informasi di perpustakaan, mau atau tidak mau pihak perpustakaan harus menyediakan "database" atau basis data yang berisi bahan pustaka untuk dimanfaatkan oleh pemustaka. Tentunya ketersediaan database tersebut juga didukung oleh beberapa komputer client yang berfungsi sebagai sarana membaca bahan pustaka elektronis. Salah satu bentuk ketersediaan bahan pustaka elektronik di perpustakaan perguruan tinggi 
adalah peralihan media local content dalam format digitalisasi yang selanjutnya disebut "electronic local content". Menurut Arianto (2014), dalam kehidupan kampus local content memiliki nilai yang mana fungsi nilai tersebut tidak hanya penting buat civitas akademika, namun juga penting bagi seluruh lapisan masyarakat.

\section{Kualitas Layanan Untuk Meningkatkan Mutu}

Dalam layanan perpustakaan kualitas sangat diperhatikan guna memenuhi kebutuhan pemustaka. Dalam sebuah layanan kualitas harus memberikan perhatian sehingga dapat diukur dari sisi persepsi antara pengolah ataupun pemanfaatanya. Dengan demikian kualitas merupakan dimensi ukuran yang membutuhkan evaluasi untuk mengidentifikasi kualitas layanan. Menurut Wijaya (2012), pencapaian derajat karakteristik bisa memenuhi syarat merupakan salah satu kebutuhan maupun harapan dan biasanya diwajibkan. Tjiptono (2009), mengungkapkan meskipun kualitas dapat dimanfaatkan secara universal memiliki beberapa kesamaan, yaitu:

1. Kualitas memenuhi ataupun melebihi sebuah harapan

2. Keterlibatan kualitas mencakup beberapa elemen

3. Kualitas merupakan kondisi yang dinamis.

Dari beberapa pendapat diatas dapat disimpulkan kualitas layanan merupakan penekanan utama dalam upaya memperoleh layanan yang berkualitas sehingga pemustaka merasa puas. Hernon (2008) menyatakan untuk mewujudkan layanan berkualitas organisasi mempengaruhi sebuah sistem yang telah dipakainya. Hal senada juga diungkapkan Kotler dalam Nurita Andriani (2014), menyatakan bahwa sebuah kepuasan yang diperoleh oleh konsumen merupakan sebuah manifestasi seseorang setelah memperoleh perbandingan sebuah hasil atau produk terhadap kinerja yang diharapkan. Adanya pendapat tersebut menggambarkan bahwa pemustaka sebagai konsumen di perpustakaan akan merasa dihargai ketika bahan pustaka telah tersedia sesuai dengan harapan mereka. Penelitian yang dilakukan Supriyanto (2017), bahwa untuk membangun sebuah perpustakaan yang bermutu memerlukan sebuah strategi dan inovasi. Salah satu inovasi untuk meningkatkan layanan perpustakaan disamping ketersediaan bahan pustaka, dengan strategi rebanding yaitu strategi yang berusaha menghilangkan kesan kaku pada perpustakaan.

\section{PENUTUP}

Berdasarkan hasil kajian yang dilakukan oleh penulis dari berbagai jurnal ataupun penelitian terkait "Strategi Peningkatan Mutu Perpustakaan Perguruan Tinggi Melalui Ketersediaan Bahan Pustaka", fokus artikel ini adalah ketersediaan bahan pustaka. Maka dalam artikel ini dapat ditarik kesimpulan bahwa untuk meningkatkan mutu layanan perpustakaan adanya ketersediaan bahan pustaka. Ketersediaan bahan pustaka ini tentunya, tidak sekedar "tersedia", namun ketersediaan bahan pustaka meliputi kelengkapan dan kemutakhiran bahan pustaka. Kelengkapan disini meliputi ketersediaan dalam berbagai bentuk, baik itu cetak ataupun non cetak, sedangkan kemutakhiran disini meliputi bahwa bahan pustaka yang ada di perpustakaan selalu mengikuti perkembangan ilmu pengetahuan dan teknologi (up to date). 


\section{DAFTAR PUSTAKA}

Andriani, Nurita dan Arief, Mohammad. (2014). Pengaruh Strategi Experimental Marketing Terhadap Kepuasan Pengunjung Museum Sepuluh Nopember Surabaya. Jurnal Studi Manajemen Dan Bisnis. Vol.1 (1), 55. Dapat diakses di https://doi.org/10.21107/jsmb.v1i1.1515

Arianto, M Solihin. (2014). Diseminasi informasi: Strategi pengelolaan local content. Seminar Nasional Diseminasi Informasi Local Content: Peluang dan Tantangan dari Sudut Pandang Cyberlaw. Solo: Perpustakaan Universitas Negeri Solo. 18 Juni 2014

Brophy, Peter. (2005). Library Academic Development, USA: Facet

Case, Donald O. (2002). Seeking, Needs, and Behaviour. Hawaii: Academic Press

Evans, G. Edward. (2006). Developing Collectins and Information Center. Hawaii: Libraries Unlimeted.

Handari, Budi. (2016). Peran Perpustakaan Dalam Meningkatkan Mutu Perguruan Tinggi. Libraria Jurnal Perpustakaan 4(1):127. diakses di https://www.researchgate.net/publication/311477627_peran_perpustakaan_dalam_m eningkatkan_mutu_perguruan_tinggi. doi: 10.21043/libraria.v4i1.1247

Herlina. (2006). Pengembangan Perpustakaan Dan Aspeknya. Palembang: Noerfikri

Hernon, Petter and Ellen Altman. (2008). Expectations Library Service. Chicago: American Library Association.

Fatmawati, Endang. (2010). Seni Perpustakaan. Semarang: Universitas Diponegoro

Kotler, Philip. (2009). Marketing management; thirteenth edition. New Jersey: Pearson Prentice Hall.

Kusumaningtyas, Mahayu dan Arya, Dian. (2013). Pengaruh Ketersediaan Koleksi Perpustakaan Terhadap Tingkat Kunjungan di Perpustakaan Institut Teknologi Nasional. Edulib Journal Of Library And Information Science. Vol. 3(2).

Dapat diakses di https://webcache.googleusercontent.com/search?q=cache:oTn45qG6MoQJ:https://ejournal.up i.edu/index.php/edulib/article/view/4154+\&cd=1\&hl=id\&ct=clnk\&gl= id

Marsudi Muhammad. (2016). Manajemen Mutu: Aplikasi Dalam Bidang Pendidikan. Jakarta: Media Akademi

Martono, E. (1987). Perpustakaan Sebagai Sumber Informasi Dan Pembelajaran. Jakarta: Karya Utama.

Moenir, A. S. (1995). Pengantar Pelayanan Umum. Jakarta: Bumi Aksara.

Sa'diyah, Lailatus. (2016). Hubungan Ketersediaan Koleksi Perpustakaan Dan Kepuasan Pemustaka Di Perpustakaan Pasca Sarjana (UIN) Sunan Kalijaga Yogyakarta (Menurut Persepsi Mahasiswa). Dapat Diakses di http://digilib.uinsuka.ac.id/20744/1/1420010017_bab-i_iv-atau-v_daftar-pustaka.pdf

Sarwono. (2010). Pengembangan Perpustakaān Perguruan Tinggi. Jakarta: Erlangga

Supriyanto. (2017). Strategi Membangun Perpustakaan Bermutu. Jurnal Manajemen Dan Supervisi Pendidikan. Vol. 2(1), 55. dapat diakses di http://journal2.um.ac.id/index.php/jmsp/article/download/1939/1155

Tjiptono, Fandy. (2009). Total Quality Management. Edisi Revisi. Yogyakarta: Andi.

Wijaya, David. (2012). Pemasaran Pendidikan Dan Jasa. Jakarta: Erlangga.

Yuven, Yuni. (2010). Pedoman Pengembangan Perpustakaan Perguruan Tinggi. Semarang: Erlangga. 